\title{
EVALUASI PENGELOLAAN DANA BANTUAN OPERASIONAL KESEHATAN DI PUSKEMAS III DENPASAR SELATAN DAN JARINGANNYA DI DENPASAR, BALI
}

\author{
Andrew Paul*, Pande Putu Januraga \\ Program Studi Sarjana Kesehatan Masyarakat, Fakultas Kedokteran, Universitas Udayana \\ Alamat: Jalan PB Sudirman, Denpasar, Bali 80232
}

\begin{abstract}
ABSTRAK
Pemerintah telah membantu Puskesmas dan jaringannya di setiap daerah melalui dana Bantuan Operasional Kesehatan. Tujuan penelitian ini adalah untuk mengkaji manfaat dana BOK yang diterima oleh Puskesmas dan yang dirasakan oleh masyarakat. Penelitian dilakukan dengan metode kualitatif melalui wawancara mendalam terhadap Kepala Puskesmas, Kepala Tata Usaha, Bendahara BOK, Penanggungjawab Promotif Preventif, Penanggungjawab KIA/KB dan Imunisasi, serta wawancara mendalam terhadap beberapa pengguna yang biasa menggunakan jasa Puskesmas. Manfaat dana BOK untuk Puskesmas ditinjau dari segi manajemen untuk mendukung kegiatan promotif preventif serta dapat memperluas cakupan program. Berikutnya terpenuhinya sumber biaya untuk kegiatan yang mencakup SPM sehingga dapat terlaksana sesuai jadwal. Kemudian kegiatan Kesehatan Ibu dan Anak serta Imunisasi dapat berjalan dengan baik. Sedangkan manfaat dari segi operasional adalah dapat menjangkau lapisan masyarakat seluas-luasnya melalui kegiatan di luar Puskesmas. Manfaat dana BOK untuk masyarakat dalam hal kualitas layanan adalah adanya peningkatan dalam pelayanan. Sedangkan manfaat dalam hal kemudahan akses adalah dalam hal antrian loket tidak lagi terlalu lama. Privatisasi juga menjadi jauh lebih baik karena sudah tersedia lebih banyak ruangan-ruangan pemeriksaan. Untuk ke depannya diharapkan agar juknis operasional dana BOK dapat diperbaharui. Untuk seluruh staf Puskesmas agar pelayanan yang sudah baik tetap dipertahankan bahkan ditingkatkan.
\end{abstract}

Kata Kunci: BOK, Promotif dan Preventif, Manfaat

\begin{abstract}
The Government has assisted Puskesmas (the Public Health Center) and its networks through the Health Operational Assistance aids. The purpose of this study was to examine the benefits of the funds were received by Puskesmas and felt by the community. This research using qualitative methods through profound interviews with staffs of Puskesmas as well as with several users who used the Puskesmas services. The benefits in terms of management are to support promotive preventive activities and to expand the scope of the program. Then the fulfillment of funding sources for activities. Afterwards the Maternal and Child Health activities and Immunization can run well. The benefit from an operational perspective is can reach the society through activities outside Puskesmas. The benefit for the community in terms of service quality is an increase in service. In terms of ease of access is that the queue is no longer too long. It is also much better in term of privacy because more rooms are available for doing examintaion. Further, the Puskesmas hopes the operational technical instructions for aid funds can be updated. For all staff to keep maintain the good service even to improve it.
\end{abstract}

Keywords: Health Operational Assistance Funds, Promotive and Preventive, Benefit

\section{PENDAHULUAN}

Pembangunan kesehatan merupakan bagian integral dari pembangunan nasional dalam rangka mewujudkan visi misi Presiden dan implementasi Nawa Cita yang kelima, yaitu meningkatkan kualitas hidup manusia Indonesia. Untuk mewujudkan derajat kesehatan masyarakat yang setinggi-tingginya, diselenggarakan upaya kesehatan perorangan dan upaya kesehatan masyarakat, dengan pendekatan promotif, preventif, tanpa meninggalkan kuratif dan rehabilitatif secara terpadu, menyeluruh, dan berkesinambungan (Permenkes RI, 2015). Pemerintah Pusat telah membantu Puskesmas dan jaringannya di setiap daerah demi meringankan kebutuhan biaya operasional melalui kucuran dana Bantuan Operasional Kesehatan (BOK). Realisasi BOK telah dimulai pada pertengahan tahun 2010 dan terus ditingkatkan pada tahuntahun berikutnya. Hal ini nyata dari komitmen dan realisasi bantuan pemerintah pusat kepada daerah yang terus 
meningkat. Berdasarkan Laporan Realisasi Penggunaan Dana DAK Bidang BOK pada bulan Juni 2019, dilaporkan bahwa pada tahun 2010 dana BOK yang dialokasikan sebesar Rp. 216 milyar. Tahun 2011 meningkat menjadi Rp. 932 milyar. Dan tahun 2019 meningkat menjadi Rp. 8,358 triliun (Permenkes, 2019).

Peraturan Menteri Kesehatan Republik Indonesia Tahun 2014 Tentang Pusat Kesehatan Masyarakat, menerangkan bahwa upaya kesehatan wajib yang dapat dibiayai dari dana BOK mencakup upayaupaya kesehatan promotif dan preventif yang meliputi: (1) Pembayaran transport petugas Puskesmas, Posyandu, Poskesdes, (2) Pembayaran transport kader dan masyarakat yang terlibat dalam proses pelayanan kesehatan dan pertemuan manajemen, (3) Operasional posyandu (transport dan alat tulis kantor), (4) Operasional Poskesdes (transport, alat tulis kantor, fotokopi, rapat di desa atau kelurahan, (5) Pembelian bahan kontak, (6) Penggandaan dan alat tulis rapat dalam rangka Mini Lokakarya (minlok),

Pembelian konsumsi rapat dalam rangka minlok puskesmas, (8) Pembelian bahan Pemberian Makanan Tambahan (PMT) penyuluhan, (9) Uang penginapan (akomodasi) dan uang harian, bila diperlukan sesuai aturan yang berlaku (khusus untuk desa terpencil atau yang sulit dijangkau) (Permenkes, 2014).

Melihat jumlah dana BOK yang meningkat begitu signifikan yang dimulai pada tahun 2010 sebesar Rp. 216 milyar menjadi Rp. 8.358 triliun pada tahun 2019 sesuai penjelasan diatas, maka dapat dikatakan bahwa dana BOK ini sangat membantu Puskesmas dalam meningkatkan kualitas hidup masyarakat di Indonesia. Dalam arti kata lain bahwa pemerintah pusat mengganggap hal tersebut sebagai sesuatu yang penting. Dari sinilah penulis tertarik untuk meneliti bagaimana penggunaan dana BOK di Puskesmas secara lebih mendetail.

Puskemas III Denpasar Selatan terletak di Jalan Glogor Carik No. 17 daerah Pemogan, Kecamatan Denpasar Selatan, Kota Denpasar. Daerah ini adalah wilayah urban area (wilayah yang mempunyai kegiatan utama bukan di sektor pertanian dengan susunan fungsi kawasan sebagai tempat pemukiman perkotaan) yang padat penduduk, dimana kenyataannya bahwa di sekeliling Puskesmas III Denpasar Selatan memang merupakan kawasan padat penduduk. Penataan ruang di Puskesmas cukup bagus dan Puskesmas ini memiliki ruang Unit Gawat Darurat, Laboratorium mini meski sederhana, serta ada 22 buah ruangan lainnya. Kemudian daya jangkau pelayanan Puskesmas III Denpasar Selatan cukup besar yaitu menaungi 24 posyandu aktif yang tersebar di 2 kelurahan yaitu Pemogan dan Pulau Serangan.

Puskemas III Denpasar Selatan pertama kali menerima dana BOK tahun 2015 yaitu sebesar Rp. 215 juta dan mengalami peningkatan yang cukup besar menjadi Rp. 387 juta pada tahun 2019. Dari laporan Realisasi Penggunaan dana BOK tahun 2019, dana BOK yang diterima dari pemerintah dipergunakan paling banyak untuk kegiatan promotif dan preventif yaitu sebesar Rp. 249 juta (atau sekitar $64,3 \%$ ), kemudian untuk upaya kesehatan lainnya sebesar Rp. 118.5 juta (sekitar 30\%), dan sisanya sebesar Rp. 19.35 juta (sekitar $5 \%$ ) digunakan untuk upaya manajemen. 
Bantuan Operasional Kesehatan (BOK) adalah bantuan dari pemerintah pusat kepada pemerintah daerah untuk Puskesmas dan jaringannya serta Poskesdes/Polindes, Posyandu dan UKBM lainnya, untuk mempercepat pencapaian target prioritas nasional, khususnya SDG's (Sustainable Development Goals), dalam menyelenggarakan Pelayanan Kesehatan Promotif dan Preventif KIA-KB, Gizi, Imunisasi, Kesehatan Lingkungan, Promosi Kesehatan, dan Pengendalian Penyakit.

Bantuan Operasional Kesehatan (BOK) umumnya digunakan untuk kegiatan upaya kesehatan yang bersifat promotif dan preventif di Puskesmas serta jaringannya, termasuk Posyandu dan Poskesdes, dalam rangka membantu pencapaian target SPM (Standar Pelayanan Minimal) Bidang Kesehatan di Kabupaten atau Kota untuk mempercepat pencapaian target SDG's. Selain itu, dana BOK juga dialokasikan untuk mendukung pelaksanaan manajemen BOK di Dinas Kesehatan Kabupaten atau Kota.

Sesuai Petunjuk Teknis Bantuan Operasional Kesehatan yang dikeluarkan oleh Kementerian Kesehatan Republik Indonesia tahun 2015, ruang lingkup kegiatan yang boleh didanai dari BOK menurut buku Petunjuk Teknis BOK 2015 adalah sebagai berikut (Permenkes, 2015).

a. Minimal $60 \%$ dari total alokasi dana BOK Puskesmas digunakan untuk Program Kesehatan Prioritas melalui berbagai kegiatan yang memiliki daya ungkit tinggi untuk pencapaian tujuan MDG's pada bidang kesehatan.

b. Maksimal $40 \%$ dari total alokasi dana BOK Puskesmas digunakan untuk
Program Kesehatan lainnya serta Manajemen Puskesmas.

Rincian ruang lingkup program kesehatan dan manajemen puskesmas meliputi program kesehatan prioritas, program kesehatan lainnya, serta manajemen Puskesmas.

Pusat Kesehatan Masyarakat adalah fasilitas pelayanan kesehatan yang menyelenggarakan upaya kesehatan masyarakat dan upaya kesehatan perorangan tingkat pertama, dengan lebih mengutamakan upaya promotif dan preventif agar derajat kesehatan masyarakat di wilayah kerja mereka bisa dicapai setinggi-tingginya. Puskesmas juga merupakan suatu unit pelaksana fungsional yang berfungsi sebagai pusat pembangunan kesehatan, pusat pembinaan peran serta masyarakat dalam bidang kesehatan, serta pusat pelayanan kesehatan tingkat pertama yang menyelenggarakan kegiatan secara menyeluruh, terpadu, dan berkesinambungan pada suatu masyarakat yang bertempat tinggal pada suatu wilayah tertentu (Sulaeman, 2009).

Pusat Kesehatan Masyarakat adalah salah satu jenis fasilitas kesehatan masyarakat tingkat pertama yang memiliki peranan penting dalam sistem kesehatan nasional, khususnya subsistem upaya kesehatan sehingga dapat meningkatkan aksesibilitas, keterjangkauan, dan kualitas pelayanan dalam rangka meningkatkan derajat kesehatan masyarakat. Ini sesuai dengan Peraturan Menteri Kesehatan Republik Indonesia nomor 75 tahun 2014, tentang Pusat Kesehatan Masyarakat.

Pendanaan di Puskesmas bersumber dari Anggaran Pendapatan dan Belanja Daerah (APBD), Anggaran Pendapatan dan 
Belanja Negara (APBN), serta sumbersumber lain yang sah dan tidak mengikat. Pengelolaan dana di Puskesmas tersebut dilaksanakan sesuai dengan ketentuan peraturan perundang-undangan.

Undang-Undang Nomor 32 tahun 2004 tentang Pemerintahan Daerah dan Undang-Undang 33 tahun 2004 tentang Perimbangan Keuangan antara Pemerintah Pusat dan Daerah menunjukkan bahwa sebagian besar urusan Pemerintahan telah diserahkan kepada Daerah termasuk Bidang Kesehatan. Konsekuensi logis dari penyerahan ini adalah segala sesuatu yang menyangkut perencanaan, pembiayaan dan pelaksanaan yang sepenuhnya menjadi tanggung jawab Pemerintah Daerah (Ayuningtyas, 2014).

\section{METODE PENELITIAN}

Penelitian ini telah sesuai dengan kode etik penelitian oleh Komisi Etik Penelitian Litbang FK Unud/RSUP Sanglah dengan nomor 158/UN14.2.2.V.3/LT/2020. Metode penelitian yang dilakukan adalah dengan melakukan wawancara terhadap Kepala Puskesmas, Kepala Tata Usaha, Bendahara BOK, Penanggungjawab program Imunisasi dan KIA/KB, serta beberapa masyarakat yang biasa menggunakan jasa Puskemas III Denpasar Selatan dan jaringannya. Jadi metode penelitian yang digunakan merupakan jenis penelitian kualitatif.

Metode penelitian kualitatif adalah metode yang lebih menekankan pada aspek pemahaman secara mendalam terhadap suatu masalah daripada melihat permasalahan untuk penelitian generalisasi. Menurut Sugiyono (2010), metode penelitian kualitatif adalah penelitian yang digunakan untuk menyelidiki, menemukan, menggambarkan, dan menjelaskan kualitas atau keistimewaan dari pengaruh sosial yang tidak dapat dijelaskan, diukur atau digambarkan melalui pendekatan kuantitatif.

Penulis melakukan penelitian di Puskesmas III Denpasar Selatan, beralamat di Jalan Glogor Carik No. 17 daerah Pemogan, Kecamatan Denpasar Selatan, Kota Denpasar. Adapun waktu penelitian adalah dari bulan Februari 2020 sampai bulan Juni 2020. Penulis datang melakukan penelitian dan wawancara mendalam sesuai dengan kebutuhan.

\section{HASIL DAN DISKUSI}

\section{Manfaat Dana BOK terhadap Puskesmas Alokasi dan Realisasi}

Dari hasil penelitian yang didapat, maka alokasi dana BOK untuk Puskesmas III Denpasar Selatan untuk tahun kerja 2019 adalah sebesar Rp. 387.000.000. Sesuai Petunjuk Teknis BOK, minimal 60\% dari total alokasi dana harus digunakan untuk program kesehatan prioritas yaitu kegiatan promotif dan preventif, kemudian maksimal $40 \%$ digunakan untuk program kesehatan lainnya serta manajemen puskesmas.

Penggunaan dana BOK tahun 2019 untuk Puskesmas III Denpasar Selatan belum terealisasi $100 \%$ yaitu sebesar 98.219\% yaitu sebesar Rp. 380.110 .400 dari dana sebesar Rp. 387.000.000. Dengan penggunaan sebesar $98.219 \%$ sudah masuk kategori baik karena sudah mendekati $100 \%$. Berdasarkan penelitian laporan, diketahui bahwa penggunaan dana BOK sudah sesuai Juknis BOK yaitu sebesar Rp. 
255.098.790 (atau 65.917\%) digunakan untuk program promotif dan preventif, sebesar Rp. 105.809 .670 (atau 27.341\%) digunakan untuk upaya kesehatan lainnya, dan sebesar Rp. 19.199.070 (atau 4.961\%) digunakan untuk dukungan manajemen puskesmas.

\section{Manfaat dana BOK terhadap Puskesmas ditinjau dari Segi Manajemen}

Dari hasil wawancara mendalam yang dilakukan terhadap staf Puskesmas, maka manfaat dana BOK terhadap Puskesmas III Denpasar Selatan ditinjau dari segi Manajemen adalah untuk mendukung kegiatan promotif dan preventif yang ada, serta meningkatkan kinerja program-program yang ada didalamnya. Manfaat berikutnya adalah terpenuhinya sumber biaya untuk kegiatan yang mencakup SPM (Standar Pelayanan Minimal) sehingga dapat terlaksana sesuai jadwal. Dan manfaat yang ketiga adalah kegiatan Kesehatan Ibu dan Anak serta Imunisasi dapat terlaksana sesuai dengan rencana yang telah dibuat.

Hal ini sesuai kutipan wawancara sebagai berikut.

"Tujuan adanya dana BOK di Puskesmas dilihat dari segi manajemen adalah untuk menunjang kegiatan yang mencakup promotif dan preventif guna meningkatkan cakupan program" (Informan I).

"Sumber biaya dari kegiatan yang mencakup SPM" (Informan II).

"Kegiatan BOK yang tertuang dalam SPM dapat terlaksana sesuai jadwal" (Informan III). "Pelaksanaan Imunisasi rutin dapat dilaksanakan sehingga data yang didapat dapat dijadikan bahan untuk penyusunan laporan manajemen Puskesmas" (Informan IV).
"Kegiatan kesehatan ibu dan anak dapat dilaksanakan sesuai rencana yang disusun" (Informan V).

Dalam penelitian yang dilakukan oleh Fatmah Afrianty Gobel, pengajar sekaligus mahasiswa program Pasca Sarjana Program Studi S3 Ilmu Kedokteran Universitas Airlangga Surabaya, tahun 2012 yang berjudul "Mengenal Dana Bantuan Operasional Kesehatan," dituliskan bahwa kegiatan promotif dan preventif adalah kegiatan utama dalam suatu Puskesmas. Kegiatan ini termasuk dalam program pelayanan kesehatan esensial yang dicanangkan oleh pemerintah. Dari dana BOK yang dikucurkan kepada Puskesmas, minimal $60 \%$ harus digunakan untuk pembiayaan kegiatan promotif dan preventif. Kegiatan promotif dan preventif yang dilakukan oleh Puskesmas III Denpasar Selatan mencakup banyak pelayanan kesehatan yang penting di masyarakat, antara lain : Pelayanan Kesehatan Ibu dan Balita, Pelayanan Kesehatan Anak Balita dan Pra Sekolah, Pelayanan Kesehatan Anak Usia Sekolah dan Remaja, Kegiatan Imunisasi, Pelayanan Kesehatan Lanjut Usia, Program Promosi, Pelayanan Kesehatan Lingkungan, Pelayanan Pencegahan dan Pengendalian Penyakit Menular Langsung, Pelayanan Pencegahan dan Pengendalian Penyakit Tidak Menular, Pengendalian Vektor, dan Pelayanan Pencegahan dan Pengendalian Masalah Kezwa dan Napza.

Kemudian lebih lanjut dijelaskan oleh Fatmah Afrianty Gobel (2012) bahwa yang dimaksud dengan SPM adalah kegiatan yang berada di area Upaya Kesehatan Dasar yaitu berupa kunjungan ibu hamil, pelayanan anak balita, kunjungan ke desa- 
desa yang ada di wilayah kerja Puskesmas, pemberian makanan pendamping ASI pada anak usia 6-24 bulan dari keluarga miskin, untuk menangani balita gizi buruk, dan penjaringan kesehatan siswa $\mathrm{SD}$ dan setingkat. Dalam pelaksaan SPM, tenaga kesehatan dari Puskesmas III Denpasar Selatan banyak melakukan kunjungan bukan ke desa-desa tetapi ke banjar-banjar (karena di Bali).

Membahas mengenai Kesehatan Ibu dan Anak serta Imunisasi, Fatmah Afrianty Gobel dalam penelitiannya menuliskan bahwa tujuan khusus microplanning sesuai Instruksi Menteri Kesehatan Republik Indonesia tahun 1989 adalah mengembangkan dan membina pos-pos pelayanan terpadu KB (Keluarga Berencana) Kesehatan di setiap desa wilayah kerja Puskesmas sesuai dengan kemampuan yang dimiliki dan masalah yang dihadapi, serta perencanaan yang diarahkan pada lima program terpadu KB kesehatan, imunisasi, dan penanggulangan diare. Puskesmas III Denpasar Selatan telah menggunakan dana BOK semaksimal mungkin agar pelaksanaan Imunisasi dan KIA/KB dapat dilakukan secara optimal dengan melakukan kunjungan ke banjarbanjar yang merupakan wilayah kerja Puskesmas III Denpasar Selatan.

\section{Manfaat dana BOK terhadap Puskesmas ditinjau dari Segi Operasional}

Dari hasil wawancara mendalam yang dilakukan terhadap staf Puskesmas, maka manfaat dana BOK terhadap Puskesmas III Denpasar Selatan ditinjau dari segi Operasional adalah dapat menjangkau lapisan masyarakat seluasluasnya melalui kegiatan-kegiatan di luar
Puskesmas dan semua semua kegiatan Puskesmas dapat diselenggarakan sesuai dengan rencana.

Hal ini sesuai kutipan wawancara sebagai berikut.

"Dipakai untuk membantu dana operasional dalam melakukan kunjungan ke banjar-banjar yang termasuk dalam lingkungan kerja Puskesmas III Densel" (Informan II).

"Dana BOK dipakai untuk meningkatkan kinerja kegiatan yang dilakukan di luar Puskesmas" (Informan III).

"Dapat melaksanakan kegiatan promotif dan preventif sesuai rencana yang sudah disusun" (Informan I).

"Dana BOK salah satunya dipakai untuk membantu bidan dalam berkunjung ke bumil dan bumil resti, ke banjar-banjar dan ke pantipanti" (Informan V).

Pemanfaatan dana BOK digunakan untuk dana manajemen dan dana operasional di Puskesmas (Sutisna, 2009). Sedangkan salah satu tujuan khusus dari BOK menurut buku Petunjuk Teknis Bantuan Operasional Kesehatan tahun 2015 adalah menyediakan dukungan dana operasional program bagi Puskesmas demi pencapaian program kesehatan prioritas nasional (Permenkes, 2015).

Di Puskesmas III Denpasar Selatan, kegiatan-kegiatan di luar Puskesmas yang memakai dana BOK antara lain kunjungan ke banjar-banjar untuk kegiatan Upaya Kesehatan Anak dan Balita, Penyuluhan tentang Program Kesehatan HIV/AIDS, IMS, TB, Pneumonia, Diare, PTM, DBD, Rabies, P4K, Faktor Resiko Bumil, Gizi, Kekerasan terhadap perempuan/anak, Kesehatan Jiwa, Swamedikasi Obat, serta Penemuan kasus secara dini/Penyelidikan Epidemiologi dan Pemantauan Jentik 
Berkala (Sumber: Puskesmas III Denpasar Selatan).

Darmawan \& Sjaaf (2016) mengatakan bahwa salah satu indikator keberhasilan Puskesmas adalah terselenggaranya kegiatan-kegiatan di luar Puskesmas agar dapat menjangkau segenap lapisan masyarakat secara luas yaitu berupa kunjungan rumah dan pengorganisasian masyarakat. Masyarakat di Pulau Bali sangat kental nuansanya dengan apa yang disebut dengan banjar. Mereka sangat patuh sekaligus antusias jika ada kegiatan di banjar mereka. Dalam kaitannya dengan kondisi inilah pihak Puskesmas III Denpasar Selatan melakukan programprogram kesehatan di luar Puskesmas seperti yang sudah disebutkan diatas, sekaligus dana BOK yang diterima dapat dimanfaatkan untuk kegiatan operasional secara optimal.

Hal berikutnya yang tidak kalah penting adalah bahwa semua kegiatan Puskesmas dapat terlaksana sesuai dengan rencana yang sudah disusun melalui RPK. RPK bukan hanya bicara soal jadwal pelaksanaan program-program kesehatan, tetapi sekaligus mencakup biaya yang dibutuhkan untuk setiap program kesehatan. Dalam suatu kegiatan seminar yang diselenggarakan di Makassar pada tanggal 29 September 2011 dengan topik

Monitoring dan Evaluasi Kebijakan BOK dan JAMPERSAL yang disampaikan pada Forum Nasional II: Jaringan Kebijakan Kesehatan Indonesia dan Penetapan Agenda ke Evaluasi Kebijakan Kesehatan, Drg. Tini Suryanti Suhandi, M.Kes (2011), selaku Kepala Biro Perencanaan dan Anggaran Kementerian Kesehatan Republik Indonesia, menyampaikan bahwa penyusunan RPK harus melibatkan semua penanggungjawab program kesehatan di Puskesmas, agar kegiatan yang dilakukan di luar Puskesmas dapat memenuhi paling tidak 90\% dari masalah kesehatan yang dijumpai di masyarakat. Penyusunan RPK juga harus disertai dengan besaran biaya yang dibutuhkan agar program kesehatan yang dimaksud dapat dilakukan dengan optimal.

Dalam pelaksanaannya di Puskesmas III Denpasar Selatan, semua yang bertanggungjawab untuk setiap program kesehatan, sudah mulai menyusun RPK sejak bulan April 2018 untuk tahun kerja 2019. RPK ini dievaluasi dan dibenahi setiap bulan sampai akhirnya final di bulan Desember 2018. Maksud evaluasi dan pembenahan adalah dengan melihat perkembangan pelaksanaan program yang sedang berjalan dalam tahun kerja 2018. Mana program yang sekiranya harus ditambah atau mana program yang sekiranya bisa dihilangkan. Dan penyusunan RPK ini juga disertai dengan besaran biaya yang dibutuhkan agar program yang disusun dapat terlaksana.

\section{Manfaat Dana BOK Terhadap Masyarakat Manfaat dana BOK terhadap Masyarakat Ditinjau dari Segi Kualitas Layanan}

Dari hasil wawancara mendalam yang dilakukan terhadap masyarakat, maka manfaat dana BOK terhadap masyarakat pengguna jasa Puskesmas III Denpasar Selatan ditinjau dari segi Kualitas Layanan adalah bahwa Puskesmas III Denpasar Selatan mengalami peningkatan dalam hal pelayanan. Petugas-petugasnya bekerja dengan ramah dan baik. Informasiinformasi kesehatan, terutama imunisasi 
dan KIA/KB, sudah diberikan dengan sangat jelas dan terperinci.

Hal ini dapat dilihat dari beberapa kutipan wawancara sebagai berikut.

"Kualitas sudah baik. Petugas ramah. Pelayanannya sekarang cepat" (Informan IV).

"Lama pelayanan semakin cepat dan meningkat. Tidak perlu lama-lama di Puskesmas apalagi dalam masa Covid seperti sekarang ini" (Informan VIII).

"Ya. Sekarang meningkat jauh pelayanannya. Ada informasi-informasi tambahan dalam program KB yang sedang saya jalankan. Ada penjelasan-penjelasan yang lebih detail soal program KB. Stafnya ramah-ramah" (Informan I).

"Sekarang pelayanan sudah lebih bagus. Banyak dijelaskan lebih detail tentang imunisasi apa saja yang harus diberikan kepada anak saya" (Informan VII).

"Sekarang sudah bagus. Petugas memberikan informasi lebih jelas dan sabar-sabar orangnya" (Informan XII).

Dana BOK mulai diterima oleh Puskesmas III Denpasar Selatan sejak tahun 2017. Wawancara mendalam ini dilakukan kepada masyarakat yang sudah menggunakan jasa Puskesmas diatas 3 tahun dan mereka semua sepakat bahwa mereka sudah merasakan adanya peningkatan dalam hal kualitas layanan dibandingkan 2 atau 3 tahun yang lalu. Dari data yang diperoleh, cakupan kunjungan baru rawat jalan ke Puskesmas III Denpasar Selatan tahun 2019 sebanyak 91,4\%, yang merupakan kunjungan dari dalam maupun luar wilayah kerja Puskesmas. Cakupan kunjungan baru ini meningkat sebesar 15\% dibanding tahun sebelumnya. Jadi dapat dikatakan bahwa masyarakat makin banyak yang menggunakan jasa Puskesmas
III Denpasar Selatan salah satunya karena mereka merasakan adanya peningkatan dalam hal kualitas pelayanan.

$$
\text { Dalam skripsi yang }
$$

ditulis oleh Lailatal Isro, Fakultas Ilmu Kesehatan Masyarakat, Universitas Sumatera Utara, dengan judul Studi Pengelolaan Dana Bantuan Operasional Kesehatan di Puskesmas Andowia Kabupaten Konawe Utara Tahun 2017, dijelaskan bahwa masyarakat mungkin tidak mengerti soal dana BOK. Tetapi dengan adanya dana BOK maka secara tidak langsung seharusnya pihak Puskesmas dapat memberikan pelayanan yang lebih baik lagi kepada masyarakat. Demikian juga masyarakat sekarang sudah lebih cerdas. Mereka membutuhkan bukan hanya pelayanan kesehatan tetapi juga informasi-infomasi yang berkaitan dengan pemeriksan kesehatan yang mereka lakukan.

Hal itulah yang juga dilakukan di Puskesmas III Denpasar Selatan. Dana BOK bukan hanya terfokus dipakai untuk kegiatan di luar Puskesmas, tetapi juga untuk kegiatan di dalam Puskesmas. Peningkatan dalam hal pelayanan adalah hal utama yang dilakukan. Seperti yang ditulis oleh Isro (2017) : "Percuma kegiatan yang dilakukan di luar Puskesmas berhasil dengan baik tetapi di dalam tidak mengalami peningkatan." Peningkatan pelayanan yang dilakukan oleh Puskesmas III Denpasar Selatan adalah dengan memberikan pelatihan kepada tenaga kesehatan agar yang pertama dalam memberikan pelayanan mereka harus sabar dan ramah. Kemudian segala informasi yang dibutuhkan oleh masyarakat harus dijabarkan dengan sejelas-jelasnya. 
Pemberian informasi yang dilakukan di Puskesmas III Denpasar Selatan contohnya adalah informasi mengenai Imunisasi. Kapan seorang anak harus menerima Imunisasi dan apa-apa saja jenis Imunisasinya. "Pemberian informasi yang jelas merupakan hal mutlak yang harus dilakukan oleh seorang petugas kesehatan kepada masyarakat yang datang ke Puskesmas" (Sutisna, 2009). Informasi berikut yang dilakukan oleh tenaga kesehatan di Puskesmas III Denpasar Selatan adalah soal jenis-jenis alat kontrasepsi, kelemahan dan kelebihannya. Sehingga pasien dapat memilih dan menentukan jenis kontrasepsi apa yang akan mereka gunakan. Sebagai tambahan, dalam masa COVID-19 seperti sekarang ini, diberikan penjelasan mengenai pelaksanaan kesehatan yang harus dilakukan untuk terhindar dari virus Corona serta mencegah meluasnya penyebaran virus tersebut.

\section{Manfaat dana BOK terhadap Masyarakat ditinjau dari Segi Kemudahan Akses}

Dari hasil wawancara mendalam yang dilakukan terhadap masyarakat, maka manfaat dana BOK terhadap masyarakat pengguna jasa Puskesmas III Denpasar Selatan ditinjau dari segi Kemudahan Akses adalah bahwa Puskesmas III Denpasar Selatan sudah baik dalam hal antrian dan jam buka loket sudah baik. Kemudian dalam hal Privatisasi, ruangan-ruangan sudah dipisah sesuai dengan bidang pemeriksaan yang berlaku dan bersih.

Hal ini sesuai hasil wawancara dengan kutipan sebagai berikut :
"Saat ini sudah tidak mengantri seperti dulu sehingga membuat saya yang ke Puskesmas merasa lebih aman, terutama di masa Covid seperti sekarang ini. Untuk privatisasi, sekarang sudah disediakan ruangan-ruangan yang aman (terpisah) untuk melakukan kontrol" (Informan I).

"Antrian sudah jauh lebih baik dan teratur, pemeriksaan sekarang lebih privat karena di ruangan yang terpisah-pisah" (Informan III).

"Ruangan-ruangannya sekarang sudah terpisah sehingga pemeriksaan bisa lebih maksimal untuk setiap pasien yang berkunjung" (Informan IX). "Antrian loket sudah lebih teratur. Ruangan bersih dan baik. Pelayannya ramah" (Informan $\mathrm{XI})$.

Darmawan \& Sjaaf dalam bukunya yang berjudul Administrasi Kesehatan Masyarakat, Teori dan Praktek, yang diterbitkan tahun 2016, mengatakan bahwa “Antrian loket merupakan masalah yang biasa dijumpai baik di rumah sakit maupun di Puskesmas. Siapa yang bisa menyelesaikan permasalahan tersebut dengan baik, dapat dikatakan sudah berhasil mengatasi problematika awal sebelum bicara hal-hal lainnya." Dengan adanya dana BOK, maka Puskesmas III Denpasar Selatan memiliki kelebihan dana operasional. Kelebihan inilah salah satunya dipergunakan untuk menambah loket antrian, sehingga tidak terjadi penumpukan pendaftaran pasien. Jika pasien yang datang sedikit, hanya dibuka satu loket. Sedangkan jika pasien banyak, loket kedua dibuka. Kedisiplinan dalam hal waktu adalah hal yang penting. Itu juga yang diterapkan oleh Puskesmas III Denpasar Selatan yang selalu mengusahakan tepat waktu dalam jam operasionalnya. Lebih banyak pasien yang datang sebelum jam operasional dimulai, 
sehingga jika tidak tepat waktu dalam membuka loket maka pasti terjadi penumpukan pasien.

Dalam hal privatisasi, Puskesmas III Denpasar Selatan sekarang sudah memiliki 10 ruangan sesuai jenis pemeriksaan, yaitu ruang UGD, ruang pelayanan VCT, ruang imunisasi, ruang $\mathrm{KB}$, ruang gizi, ruang $\mathrm{KIA} / \mathrm{KB}$, ruang klinik gigi, ruang laktasi, ruang konseling, dan ruang konsultasi TBC (Sumber : Puskesmas III Denpasar Selatan). Kelebihan dana yang dimiliki oleh Puskesmas karena adanya dana BOK, antara lain dipakai untuk menambah atau membangun jumlah ruangan pemeriksaan. Fatmah Afrianty Gobel dalam penelitiannya yang berjudul Mengenal Dana Bantuan Operasional Kesehatan, Universitas Airlangga 2012, menuliskan bahwa, "Dengan semakin banyaknya ruangan yang ada, tentunya pelayanan terhadap masyarakat bisa semakin cepat dan optimal. Mereka bisa segera ditangani dalam ruangan-ruangan yang terpisah sesuai dengan jenis keperluannya." Untuk masa sekarang ini bangunan dan fasilitas yang ada di Puskesmas III Denpasar Selatan sudah cukup memadai untuk melayani masyarakat. Tetapi tentu untuk jangka panjangnya harus dipikirkan hal-hal lainnya lagi.

\section{SIMPULAN}

Pertama, manfaat dana BOK terhadap Puskesmas ditinjau dari segi Manajemen adalah untuk mendukung kegiatan promotif dan preventif yang ada, serta meningkatkan kinerja program-program yang ada didalamnya. Manfaat lainnya yang dirasakan dengan adanya dana BOK adalah terpenuhinya sumber biaya untuk kegiatan yang mencakup SPM (Standar Pelayanan Minimal) sehingga dapat terlaksana sesuai jadwal. Kemudian kegiatan Kesehatan Ibu dan Anak serta Imunisasi dapat terlaksana sesuai dengan rencana yang telah dibuat. Manfaat dana BOK terhadap Puskesmas ditinjau dari segi Operasional adalah dapat menjangkau lapisan masyarakat seluas-luasnya melalui kegiatan-kegiatan di luar Puskesmas, seperti melakukan imunisasi ke TK, SD, SMP dan melakukan kunjungan ke bumil dan bumil resti, banjar-banjar, panti, di wilayah kerja Puskesmas III Denpasar Selatan. Sedangkan manfaat lainnya dengan adanya dana BOK adalah semua kegiatan Puskesmas dapat diselenggarakan sesuai dengan rencana.

Simpulan yang kedua, manfaat dana BOK dari pihak masyarakat mengenai Kualitas Layanan adalah bahwa Puskesmas III Denpasar Selatan mengalami peningkatan dalam hal pelayanan. Petugaspetugasnya bekerja dengan ramah dan baik. Informasi-informasi kesehatan, terutama imunisasi dan KIA/KB, sudah diberikan dengan sangat jelas dan terperinci. Dari segi Kemudahan Akses masyarakat mengatakan bahwa Puskesmas III Denpasar Selatan sudah baik dalam hal antriannya, jam buka loket sudah baik. Kemudian dalam hal Privatisasi, ruangan-ruangan sudah dipisah sesuai dengan bidang pemeriksaan yang berlaku dan bersih.

\section{SARAN}

Pertama, untuk ke depannya dari pihak Puskesmas mengharapkan agar juknis operasional dana BOK dapat diperbaharui. Pembaharuan yang diinginkan adalah peningkatan dalam 
jumlah serta perluasan cakupan, yaitu untuk kegiatan kuratif dan rehabilitatif serta pembelian barang-barang kesehatan.

Yang kedua, dari segi kwalitas layanan, pihak masyarakat mengharapkan agar Puskesmas III Denpasar Selatan mempertahankan dan meningkatkan kualitas layanan yang baik, serta terus menjaga kebersihan lingkungan sekitar Puskesmas yang sampai saat ini sudah terjaga dengan baik. Sedangkan yang ketiga, dari segi kemudahan akses, pihak masyarakat mengharapkan agar Puskesmas III Denpasar Selatan di kemudian hari membuat antrian online, lewat whatsapp atau short message service (sms).

\section{UCAPAN TERIMA KASIH}

Dalam penelitian ini, penulis mengucapkan terima kasih kepada yang terutama Bapak Dr. Pande Putu Januraga, M.Kes., DrPH, selaku Dosen Pembimbing yang telah banyak membantu dan meluangkan waktu untuk memberikan bimbingan, pengarahan dan saran-saran, sehingga penelitian ini dapat diselesaikan dengan baik. Kemudian kepada Ibu Nyoman Eva Sri Wahyuni, A.Md.Kep., selaku staf administrasi yang telah banyak membantu penulis dalam memberikan data-data yang diperlukan selama penulis melakukan penelitian di Puskesmas III Denpasar Selatan dan jaringannya.

\section{DAFTAR PUSTAKA}

Ayuningtyas, D. (2014). Kebijakan Kesehatan: Prinsip dan Praktik. Rajawali Pers.

Darmawan, A. S., \& Sjaaf, A. C. (2016). Administrasi Kesehatan Masyarakat: Teori dan Praktek. Rajawali Pers.
Depkes RI. (2004). Petunjuk Teknis Standar Pelayanan Minimal (SPM) Penyelenggaraan Perbaikan Gizi Masyarakat. Departemen Kesehatan Republik Indonesia Ditjen Bina Kesehatan Masyarakat Direktorat Gizi Masyarakat Jakarta.

Gobel, Fatmah Afrianty. (2011). Mengenal Dana BOK.

Instruksi Menteri Kesehatan Republik Indonesia Tahun 1989.

Isro, Lailatal. (2017). Studi Pengelolaan Dana BOK di Puskesmas Andowia Kabupaten Konawe Utara Tahun 2017.

Kementerian Kesehatan. (2014). Profil Kesehatan Indonesia Tahun 2013. In Jakarta: Kementerian Kesehatan RI. https://doi.org/351.770.212 Ind P.

Kementerian Kesehatan Republik Indonesia Tahun 2015 Tentang Program Indonesia Sehat.

Peraturan Menteri Kesehatan Republik Indonesia Nomor 75 Tahun 2014

Tentang Pusat Kesehatan Masyarakat. Peraturan Menteri Kesehatan Republik Indonesia Nomor 11 Tahun 2015 Tentang Petunjuk Teknis Bantuan Operasional Kesehatan.

Peraturan Menteri Kesehatan Republik Indonesia Nomor 43 Tahun 2016 tentang Standar Pelayanan Minimal Bidang Kesehatan.

Peraturan Menteri Kesehatan Republik Indonesia Nomor 3 Tahun 2019 Tentang Petunjuk Teknis Penggunaan Dana Alokasi Khusus Nonfisik Bidang Kesehatan.

RPK Puskesmas III Denpasar Selatan tahun 2018. 
Sugiyono. (2010). Memahami Penelitian Kualitatif. Bandung: Alfabeta. Bandung: Alfabeta.

Suhandi, Tini Suryanti. (2011). Monitoring dan Evaluasi Kebijakan BOK dan Jampersal.
Sutisna, E. S. (2009). Manajemen Kesehatan: Teori dan Praktik di Puskesmas. UGM Press.

Undang-Undang Republik Indonesia Nomor 32 Tahun 2004 Tentang Pemerintah Daerah, Pub. L. No. 32. 